\title{
Дмитро ЛЕОНОВ
}

кандидат економічних наук, профресор, ДВНЗ “Київський національний економічний університет імені Вадима Гетьмана", Київ, Україна, leonov_da@ukr.net

ORCID ID: 0000-0001-5626-3887

\section{ВПАИВ ДЕРЖАВНОГО РЕГУАЮВАННЯ НА РОЗВИТОК НЕДЕРЖАВНИХ ПЕНСІЙНИХ ФОНДІВ В УКРАЇНI}

Вступ. Розбудова ефективної пенсійної системи є для будь-якої країни одним із наріжних каменів формування соціально-економічної моделі розвитку держави. Механізми формування та використання фрінансових ресурсів пенсійної системи впливають на всі аспекти фрункціонування такої моделі. Покладання завдань організації майбутнього пенсійного забезпечення лише на якусь одну зі сторін цього процесу (державу, роботодавия, фрізичну особу) історично демонструє вразливість таких "однорівневих" моделей. Відповідно, більшість країн світу розбудовують “багаторівневі” моделі національних пенсійних систем з метою створення різних організаційних форм пенсійного забезпечення, залучення якомога більшої кількості їі учасників і фрінансових ресурсів, необхідних для забезпечення майбутніх пенсіонерів. Запровадження багаторівневої пенсійної системи в Україні ще триває. Тому дослідження проблем державного регулювання функціонування нових для вітчизняної пенсійної системи форм пенсійного забезпечення та перспектив їх розвитку залишається актуальним.

Mета - дослідити проблемні аспекти діяльності недержавних пенсійних фондів як складової багаторівневої пенсійної системи України та визначити перспективи їх розвитку з урахуванням впливу держави.

Meтоди. У статmі використані загальнонаукові методи дослідження, зокрема: історичний, порівняльний, статистичний, аналіз і синтез, індукція і дедукція, абстрагування й узагальнення.

Результати. Визначено місце недержавних пенсійних фрондів у багаторівневій пенсійній системі України. Обгрунтовано вплив і взаємозалежність діяльності НПФ та інших елементів накопичувальної складової національної пенсійної системи. Виявлено негативні аспекти впливу держави на функціонування недержавного рівня пенсійної системи загалом та НПФ зокрема, а також наслідки для розвитку діяльності НПФ гальмування органами державної влади розвитку накопичувальної складової пенсійної системи України. Сфрормульовані висновки та рекомендації щодо стимулювання структурної рефрорми національної пенсійної системи та розвитку діяльності в ній недержавних пенсійних фрондів.

Перспективи. В подальших наукових дослідженнях пропонується зосередити увагу на фрормуванні умов для розвитку повноцінного, конкурентного та належним

(с Дмитро Анатолійович Леонов, 2019 
чином регульованого третього рівня пенсійної системи (недержавного пенсійного забезпечення), гармонізації його фрункціонування $і$ взаємодії з ефективним другим (загальнообов'язковим державним) рівнем національної пенсійної системи.

Ключові слова: пенсійна система, недержавний пенсійний фонд, накопичувальний фронд, пенсійна рефрорма, недержавне пенсійне забезпечення, державне регулювання.

Бібл.: 14.

\section{Дмитрий ЛЕОНОВ}

кандидат экономических наук, профрессор, ГВУз “Киевский национальный экономический университет имени Вадима Гетьмана", Киев, Украина

\section{ВАИЯНИЕ ГОСУДАРСТВЕННОГО РЕГУАИРОВАНИЯ НА РАЗВИТИЕ НЕГОСУДАРСТВЕННЫХ ПЕНСКОННЫХ ФОНДОВ В УКРАННЕ}

Введение. Развитие эфрфективной пенсионной системы является для любой страны одним из краеугольных камней фрормирования социально-экономической модели развития государства. Механизмы формирования и использования фринансовых ресурсов пенсионной системы влияют на все аспекты фрункционирования такой модели. Возложение задач организации будущего пенсионного обеспечения лишь на какую-то одну из сторон этого процесса (государство, работодателя, фризическое лицо) исторически демонстрирует уязвимость таких "одноуровневых" моделей. Соответственно, большинство стран развивают "многоуровневые" модели национальных пенсионных систем с целью создания различных организационных фрорм пенсионного обеспечения, привлечения как можно большего числа ее участников и фринансовых ресурсов, необходимых для обеспечения будущих пенсионеров. Введение многоуровневой пенсионной системы в Украине еще продолжается. Поэтому исследования проблем государственного регулирования функционирования новых для отечественной пенсионной системы форм пенсионного обеспечения и перспектив их развития остается актуальным.

Цель - исследовать проблемные аспекты деятельности негосударственных пенсионных фондов как составной части многоуровневой пенсионной системы Украины и определить перспективы их развития с учетом влияния государства.

Методы. В статье использованы общенаучные методы исследования, в частности: исторический, сравнительный, статистический, анализ и синтез, индукция и дедукция, абстрагирования и обобщения.

Результаты. Определено место негосударственных пенсионных фоондов в многоуровневой пенсионной системе Украины. Обосновано влияние и взаимозависимость деятельности НПФ и других элементов накопительной составляющей национальной пенсионной системы. Выявлены негативные аспекты влияния государства на фрункционирование негосударственного уровня пенсионной системы в целом и НПФ в частности, а также последствия для развития деятельности НПФ торможения органами государственной власти развития накопительной составляющей пенсионной системы Украины. Сорормулированы выводы и рекомендации по стимулированию структурной реформы национальной пенсионной системы и развития деятельности в ней негосударственных пенсионных фондов. 
Перспективы. В дальнейших научных исследованиях предлагается сосредоточить внимание на формировании условий для развития полноценного, конкурентного и должным образом регулируемого третьего уровня пенсионной системы (негосударственного пенсионного обеспечения), гармонизации его фуункционирования и взаимодействии с эфрфективным вторым (общеобязательным государственным) уровнем национальной пенсионной системы.

Ключевые слова: пенсионная система, негосударственный пенсионный фонд, накопительный фонд, пенсионная реформа, негосударственное пенсионное обеспечение, государственное регулирование.

\section{Dmytro LEONOV}

Ph.D. (Economics) Prof., Kyiv National Economics University named after Vadym Hetman, Kyiv, Ukraine,leonov_da@ukr.net

ORCID ID: 0000-0001-5626-3887

\section{IMPACT OF GOVERNMENT REGULATION OF PRIVATE PENSION FUNDS DEVELOPIMENT IN UKRAINE}

Introduction. The development of an effective pension system is one of the cornerstones of forming a socio-economic model of state development for any country. The mechanisms of formation and use of financial resources of the pension system affect all aspects of the functioning of such model. Assignment of tasks of the organization of future provision of pensions only on some one of the parties of this process (state, employer, individual) is historically demonstrated the vulnerability of such "single-level" models. Accordingly, most countries in the world are developing multi-level models of national pension systems to create various organizational forms of retirement provision, to attract as many participants as possible, and to provide the financial resources needed to secure future retirees. The introduction of a multi-level pension system in Ukraine is still continues. Therefore, the study of problems of state regulation of the functioning of new forms of pension provision for the national pension system and the prospects for their development remains relevant.

Purpose of the research is to investigate the problematic aspects of the activity of non-state pension funds as a component of the multi-level pension system of Ukraine and determine the prospects for their development, taking into account the influence of the state.

Results. The place of the non-state pension funds in the multilevel pension system of Ukraine is defined. Influence and interdependence of activity of NSPF and other elements of an accumulative component of the national pension system is reasonable. Negative aspects of influence of the state on functioning of non-state level of the pension system in general and NSPF in particular and also consequences for development of activity of NSPF slowing down of development by public authorities of the accumulative making pension system of Ukraine are revealed. Conclusions and recommendations on stimulation of structural reform of the national pension system and development of activity in it the non-state pension funds are formulated.

Conclusions. During of pension reform in Ukraine the state focuses attention on reforming of a solidary component of the pension system which covers a considerable part of electorate (pensioners) and slows down introduction of mandatory funded pension system as it will not 
have fast influence on the electorate presented by the working citizens. Development of nonstate level of the pension system in the context of social and economic development by the government is practically not considered and restrains by subjective factors: a voluntary nature, low level of awareness and trust of citizens and the enterprises concerning activity of the nonstate pension funds and also purposeful (or spontaneous) actions / inaction of public authorities which complicate operating conditions of institutions of non-state pension provision. Objective factors that hamper the development of non-state pension provision are the problems of the national economy, caused by the global and national economic crises (high level of shadowing of the economy and wages, outstripping growth of the share of current consumption in monetary incomes of the population, inflation and currency devaluation, reduce the possibility of the diversification of domestic investments and insufficient accumulated pension assets in foreign currency equivalent for effective foreign investment, etc.). Necessary condition of effective influence of state regulation on development of the national pension system is observance of the legislation by public authorities and appropriate performance of the tasks assigned to these bodies, prevention of emergence of legal collisions between rules of various acts of the legislation, full economic grounding of regulatory measures. The leverage of the development of non-state pension funds may be the introduction of a mandatory accumulation level of the pension system with the involvement of non-state pension funds in the maintenance of mandatory retirement savings. It can stimulate additional voluntary pension savings, a legalization of wages of the working citizens, increase in sources of provision of pensions of the citizens and increase in level replacement of labor income in an old age and also formation of a powerful source of investment resources for financing of national economic development.

Keywords: Pension system, non-state pension fund, accumulative fund, pension reform, non-state pension provision, state regulation.

JEL Classification: E65, G23, G28, H55.

Постановка проблеми. Національні пенсійні системи країн світу відрізняються значною різноманітністю своєї архітектури. При цьому кількість рівнів у таких системах, за дослідженнями міжнародних організацій, формально коливається від одного до п'яти [1, с. 1-2]. Проте за останні десятиріччя, при реформуванні національних пенсійних систем, світова експертна спільнота пропагувала модель трирівневої пенсійної системи, яка складається із загальнообов'язкового солідарного (загальнодержавного), загальнообов'язкового накопичувального (загальнодержавного) та добровільного накопичувального (недержавного) рівнів. Саме така (трирівнева) модель була закріплена в Україні ухваленими в 2003 р. законами, якими була внормована структурна реформа національної пенсійної системи [2, 3]. Однак становлення нової багаторівневої вітчизняної пенсійної системи у подальші 15 років відбувалося вкрай нерівномірно та суперечливо. Наразі окремі структурні елементи пенсійної системи України не запроваджені (а саме, не створений другий загальнообов'язковий накопичувальний рівень), а досягнуті результати функціонування нового для вітчизняної пенсійної системи третього рівня (недержавні пенсійні фонди (НПФ) дають підґрунтя для критики пенсійної реформи взагалі, насамперед, за рахунок незначних показників динаміки розвитку цих фрінансових установ. Вагома провина в цьому має 
покладатися на державу як рушійну силу реформування національної пенсійної системи. Таким чином, дослідження проблем розвитку НПФ у пенсійній системі України, зумовлених політикою держави в цій царині, $€$ актуальним як з точки зору створення державою умов для подальшого ефективного функціонування цих фрінансових установ, так і для забезпечення розвитку національної пенсійної системи в цілому.

Аналіз останніх досліджень і публікацій. Враховуючи те, що процес науковопрактичного обґрунтування, законодавчого унормування та практичного запровадження багаторівневої пенсійної системи в Україні триває вже майже 25 років, існує значна кількість наукових публікацій, присвячених архітектурі національної пенсійної системи в цілому, а також функціонуванню НПФ в Україні як в контексті аналізу й адаптації зарубіжного досвіду діяльності подібних фінансових установ, так і з точки зору аналізу досвіду практичної діяльності вітчизняних НПФ. Серед авторів, в публікаціях наукових досліджень яких останніми роками висвітлювалися системні проблеми у розвитку накопичувальної складової пенсійної системи в Україні, можна виокремити таких дослідників, як: І. Загреба [4], Л. Лисяк [5], М. Ріппа [6] та ін. С. Теслюк [7] та В. Федина [8] свої наукові роботи присвячували проблемам державної політики щодо розвитку національної пенсійної системи та, зокрема, діяльності НПФ. Проте, незважаючи на наявність досліджень щодо національної пенсійної системи та діяльності НПФ, комплексний аналіз проблематики впливу держави на функціонування цих фрінансових установ залишається вкрай актуальним, з огляду на їх місце та роль у трирівневій пенсійній системі та можливості їх потенційного залучення для обслуговування активів другого (загальнообов'язкового накопичувального) рівня пенсійної системи.
Метою статті $€$ дослідження проблемнх аспектів діяльності недержавних пенсійних фондів як складової багаторівневої пенсійної системи України та визначення перспектив їх розвитку з урахуванням впливу держави.

Виклад основного матеріалу дослідження. За останні 15 років процеси реформування національної пенсійної системи на практиці обмежувалися здебільшого параметричними змінами умов функціонування першого загальнодержавного солідарного рівня (представленого Пенсійним фондом України (ПФУ), перманентним розгалуженням нормативного врегулювання діяльності НПФ, як фінансових установ третього (недержавного) рівня пенсійної системи, та хронічними "науково-практичними" дискусіями щодо умов запровадження та механізму функціонування другого загальнодержавного рівня (незважаючи на те, що такий механізм вже був законодавчо закріплений у 2003 р. [2], але так і не запроваджений), які загострюються та перетворюються на безплідні законодавчі ініціативи у періоди чергових виборів представників найвищого рівня державної влади (як складова їх "реформаторських" обіцянок) [4, с. 161-162; 8, c. 412-414].

Слід зазначити, що, на наш погляд, закладений у 2003 р. законодавством [2] алгоритм запровадження в Україні трирівневої пенсійної системи виявився не просто неефективним, а й таким, що загальмував реструктуризацію пенсійної системи більш ніж на півтора десятиріччя, вилучивши 3-під комплексної пенсійної реформи ціле покоління мешканців України. Зрозуміло, що у 2003 р. здавалося цілком обґрунтованим відтермінування запровадження другого (загальнообов'язкового накопичувального) рівня пенсійної системи у вигляді Накопичувального фонду (НФ) до того часу, коли буде досягнуто низки макроекономічних 
умов стабілізації пенсійної системи (безперервне зростання ВВП, досягнення бездефріцитності наявної солідарної складової пенсійної системи - ПФУ), а також напрацювання досвіду функціонування недержавних пенсійних фондів (НПФ), оскільки закріплена законом модель функціонування Накопичувального фонду за основними параметрами була подібна до моделі функціонування, встановленої для НПФ. Проте ретроспективний аналіз функціонування національної пенсійної системи в контексті умов економічного розвитку України дає змогу стверджувати, що прив'язка запровадження Накопичувального фонду до макроекономічних умов стабілізації наявної пенсійної системи (де факто - Пенсійного фронду України) та досвіду практичної діяльності НПФ була хибним рішенням держави. Недоліком запропонованої на той час моделі запровадження НФ можна вважати консервативний підхід до джерела внесків до цього фонду (як нарахування на фонд оплати праці), замість утримань внесків із заробітної плати працівника. Відповідно, запровадження внесків до НФ автоматично або збільшувало б навантаження на фонд оплати праці для роботодавців (якщо ці внески вводили б додатково), або зменшувало надходження до ПФУ (якщо внески до НФ вилучали би із загального внеску до ПФУ). Таким чином, обидва варіанти внесків до НФ у вигляді “нарахувань" суперечили досягненню закріплених законом [2] умовам запровадження НФ (у випадку додаткового навантаження на фонд заробітної плати це стримувало б зростання ВВП, а у випадку вилучення частини внесків із ПФУ гальмувало б досягнення його бездефріцитності). Водночас, жодна політична сила в Україні (яка на той час вже отримала у світі характеристику “країни із перманентними виборами") не могла дозволити собі збільшити податкове навантаження безпосередньо на громадянина-виборця. Отже, альтернативний варіант запровадження внесків до НФ як "утримання" з доходу кожної працюючої особи фрактично значив би для представників державної влади політичне самогубство.

За цих умов кожна каденція державної влади, починаючи з 2005 р., у програмних документах декларувала в переліку нагальних реформ запровадження другого загальнообов'язкового накопичувального рівня пенсійної системи (НФ), а насправді шукала аргументацію для відтермінування цього кроку, щонайменш до закінчення терміну свого перебування при владі. На жаль, одним із основних аргументів проти запровадження Накопичувального фонду влада зазвичай обирала недостатню ефективність функціонування третього (недержавного) добровільного рівня пенсійної системи. Слід зазначити, що за останнє десятиріччя переважна більшість авторів, ґрунтуючись на загальних статистичних показниках діяльності НПФ, які оприлюднюють уповноважені державні органи, дотримується аналогічної думки [4-7]. Проте, на наш погляд, суто статистичний метод дослідження в цьому випадку не може надати достатнього наукового обґрунтування без застосування історичного методу. Якщо ж застосовувати історичний метод, то можна дійти висновку, що саме діяльність держави була одним із визначальних чинників, які гальмували розвиток не тільки другого, а й третього (недержавного) рівня пенсійної системи в Україні.

Насамперед, держава безвідповідально зволікала із фрактичним запровадженням діяльності фрінансових установ недержавного рівня пенсійної системи. Відповідне законодавство було прийнято у липні 2003 р. та набуло чинності з 1 січня 2004 р. Проте прикінцевими положеннями закону [3] увесь 2004 р. було повністю відведено для напрацювання нормативно-правових актів 
державних регуляторних органів (Державної комісії з цінних паперів та фондового ринку, Державної комісії з регулювання ринків фінансових послуг). Таким чином, нормативна база, необхідна для провадження діяльності НПФ, адміністраторів НПФ та компаній з управління активами НПФ, була сфрормована лише наприкінці 2004 р., внаслідок чого перші пенсійні внески фрактично надійшли до НПФ у 2 кварталі 2005 р. (тобто через 22 місяці після прийняття відповідного закону та через рік після реєстрації за новим законодавством першого НПФ) [5, с. 270]. Стосовно двох інших видів фінансових установ, які мали право надавати послуги з недержавного пенсійного забезпечення (страхові компанії та банківські установи), передбачені зміни до законів України “Про страхування" та "Про банки і банківську діяльність”, так і не були розроблені та прийняті Верховною Радою України. Таким чином, дві альтернативні фінансові послуги з недержавного пенсійного забезпечення (довічна пенсія (довічний ануїтет) у страховій компанії та пенсійні депозитні рахунки у банку) не були своєчасно запроваджені. На перший погляд, відсутність конкуренції мала б сприяти розвитку діяльності НПФ, які залишилися єдиними фрінансовими установами, що могли надавати послуги з недержавного пенсійного забезпечення. Однак цей фрактор виявився малозначущим для розвитку НПФ та протилежним для розвитку усього недержавного рівня пенсійного забезпечення. Вочевидь, банківські установи та страхові компанії, які були відомі населенню ще з часів СРСР та продовжували розширення мережі своїх представництв і клієнтської бази за роки незалежності України, могли б сприяти просуванню серед населення інформації про додаткові можливості пенсійних накопичень. Проте цей канал просування нової фрінансової послуги фрактично заблокувала держава. НПФ, як нові фрінансові установи, не мали історично напрацьованого сприйняття ані у населення, ані у підприємствроботодавців, які могли стати засновниками/вкладниками НПФ. Крім того, держава в цьому випадку зайняла позицію "регулятора”, фрактично усунувшись від реального реформування пенсійної системи. Це було зрозуміло з бюрократичної точки зору (небажання чиновників рекламувати та відповідати за результати діяльності приватних фрінансових установ), проте абсолютно безвідповідально з точки зору державної влади як координатора пенсійної реформи. Водночас держава, як корпоративний власник, виявилася абсолютно "соціально безвідповідальною”. Маючи контрольний вплив у підприємствах державної фрорми власності, державних акціонерних товариствах (ДАК, НАК, державних холдингах), а також в акціонерних товариствах із часткою держави понад 50\%, держава не виступила системною рушійною силою у запровадженні додаткового пенсійного забезпечення працівників цих підприємств, залишивши ініціативу за менеджментом, що не набуло суттєвого поширення з огляду на зменшення прибутку підприємств в разі запровадження додаткових пенсійних внесків і фрактичного протиріччя із державною дивідендною політикою. Відповідно, просування послуг із недержавного пенсійного забезпечення відбувалося з "нульового рівня" поінформованості потенційних споживачів зусиллями, насамперед, ринкового середовища за підтримки міжнародних донорських організацій, яка постійно зменшувалася.

Варто зазначити, що на першому етапі функціонування НПФ демонстрували доволі непогані показники розвитку, незважаючи на відсутність державної інформаційної підтримки та зацікавленості держави у поширенні послуг установ третього рівня 
пенсійної системи на працівників контрольованих державою підприємств. Проте часу для зростання та напрацювання позитивного іміджу в історичній перспективі у НПФ виявилося замало. В умовах загального економічного зростання НПФ попрацювали менше чотирьох років (протягом 2005-2008рр.). Світова фрінансова криза наприкінці 2008 р. остаточно набула руйнівних наслідків для економіки України i, насамперед, для ії фрінансового ринку, зокрема і для діяльності НПФ [5, с. 271]. Проте, окрім стандартних для всіх фрінансових установ проблем із ліквідністю та знеціненням ринкової вартості сформованих інвестиційних портфелів, НПФ повною мірою відчули правовий нігілізм і саботаж з боку провідного фрінансового регулятора - Національного банку України. Зловживаючи фрормальною та неформальною "незалежністю”, НБУ, як регулятор банківського сектору фрінансового ринку, зосередився на “стабілізації" банківської системи за рахунок порушення прав споживачів ії послуг (зокрема і небанківських фрінансових установ). Це стосувалося не тільки спонукання банківських установ до порушення прав вкладників щодо доступу до їх коштів на депозитних рахунках $[9,10]$, а й у подальшому в порушенні прямих норм законодавства щодо захисту пенсійних накопичень, розміщених у банківських установах в разі їх ліквідації [11] як з боку НБУ, так і, згодом, з боку Фонду гарантування вкладів фрізичних осіб (ФГВФО), якому були передані ці функції. Такі дії НБУ та ФГВФО спричинили погіршення ліквідності, а згодом і втрату частини активів НПФ, нераціональний розпродаж інших активів НПФ за умови падіння їх ринкової вартості та фріксацію збитків НПФ від знецінення цих активів. Зрозуміло, що це призвело до загального падіння вартості активів НПФ, зменшення розміру пенсійних накопичень на індивідуальних пенсійних рахунках учасників НПФ та незворотних втрат тих учасників НПФ, які в цей період досягали пенсійного віку та розмір пенсійних вимог яких фріксувався.

Ще один прояв регуляторного саботажу з боку НБУ стосовно діяльності НПФ тривав з липня 2004 р. по лютий 2019 р. і також став підґрунтям для погіршення результативності діяльності цих фінансових установ. Йдеться про невиконання НБУ вимог законодавства про недержавне пенсійне забезпечення в частині спрощення інвестування пенсійних активів НПФ у цінні папери іноземних емітентів і придбання з цією метою вільно конвертованої валюти [3]. Фактично, НБУ завадив НПФ здійснювати валютну диверсисрікацію активів та позбавив їх потужного інструментарію хеджування, залишивши для НПФ загальний механізм отримання індивідуальної валютної ліцензії для інвестування за кордон, що технічно унеможливило здійснення таких інвестицій на іноземних організованих ринках, як це передбачено вітчизняним законодавством про недержавне пенсійне забезпечення. Якщо подивитися на показник індексу споживчих цін (інфляції) за період з початку світової фрінансової кризи (наприкінці 2008 р.) до початку 2019 р., який становив, за офріційними даними, 346,1\% [12], та порівняти його із девальвацією національної валюти, яка склала за той самий період понад $500 \%$, можна дійти висновку, що дозволена законом [3] межа вкладень пенсійних активів (до 20\% їх загальної вартості) в іноземні цінні папери потенційно забезпечила б за рахунок курсових різниць приріст вартості активів НПФ за цей період майже на $100 \%$ їх загальної початкової вартості у національній валюті (зрозуміло, без урахування коливання ринкових цін на іноземні активи та можливості отримання за ними пасивних доходів за цей період), що майже на третину компенсувало б інфляційне знецінення пенсійних накопичень в НПФ. Таким чином, 
хоча пенсійні накопичення учасників НПФ і знецінилися б у валютному еквіваленті в цілому, їх купівельна спроможність на внутрішньому ринку була б частково захищена, що, зрештою, є одним із основних завдань пенсійних накопичень для літніх людей.

Не залишилися осторонь від негативного впливу державного регулювання на діяльність НПФ і ті фрінансові регулятори, які безпосередньо за законодавством мали б опікуватись їх розвитком (наразі це - Національна комісія з цінних паперів та фондового ринку (НКЦПФР) та Національна комісія, що здійснює державне регулювання у сфері ринків фрінансових послуг (Нацфінпослуг). Що стосується негативного впливу НКЦПРФ на діяльність вітчизняних НПФ, то, зрозуміло, він не був спрямований безпосередньо проти НПФ, а полягав у послідовному погіршенню середовища їх функціонування та умов провадження інвестиційної діяльності за рахунок впровадження з 2015 р. хаотичного та недалекоглядного "реформування” державного регулювання ринку цінних паперів. Серед основних негативних фракторів, які суттєво обмежили інвестиційну діяльність НПФ на вітчизняному ринку цінних паперів, можна назвати встановлення надвисоких вимог до лістингу цінних паперів на фондових біржах і неадекватність визначення критеріїв фріктивності цінних паперів. Таким чином, значна кількість вітчизняних підприємств-емітентів реального сектору, в корпоративні цінні папери яких здійснювали інвестиції НПФ, була виведена з біржового ринку. Враховуючи те, що НПФ повинні переважну частку активів у цінних паперах інвестувати саме на біржовому ринку, такі дії регулятора призвели до суттєвого зменшення в активах фондів частки корпоративних цінних паперів (акцій та облігацій підприємств), котрі й забезпечували НПФ основний спекулятивний дохід. Отже, переважна частка інвестицій НПФ почала складатися з дозволених до інвестування фрінансових інструментів з фіксованим доходом (ОВДП та банківських депозитів) [4, с. 161; 6, с. 331], що призвело до значного обмеження дохідності пенсійних активів в цілому. Додатковим чинником падіння вартості активів НПФ та зменшення їх дохідності став перехід до оцінки вартості активів на основі прямого застосування Міжнародних стандартів фрінансової звітності (МСФЗ), які містили більш жорсткі вимоги до переоцінки активів. Це також позбавило систему оцінювання діяльності НПФ єдиної методики оцінки, з огляду на надані МСФЗ можливості формування індивідуальної облікової політики для кожного НПФ. Негативний вплив Нацкомфінпослуг, насамперед, проявився в імітації “чистки” ринку недержавного пенсійного забезпечення за рахунок виключення з реєстру фінансових установ НПФ, які тимчасово не здійснювали діяльність [13]. Практичне застосування такого права з боку Нацкомфінпослуг, з юридичної точки зору, було не безспірним, а з економічної - безглуздим, оскільки НПФ, які тимчасово не акумулювали пенсійні активи учасників, відповідно й не мали фрінансових зобов'язань перед споживачами послуг та утримувались за рахунок засновників цих НПФ згідно з вимогами законодавства. Отже, позбавляючи такі НПФ статусу фінансових установ, Нацкомфрінпослуг просто знищувала інституційну інфрраструктуру системи недержавного пенсійного забезпечення та відвертала потенційних засновників від участі у довготривалому та витратному процесі заснування таких фрінансових установ, як НПФ.

Не можна залишити поза увагою й вплив на діяльність НПФ таких органів державної влади, як Кабінет Міністрів України (КМУ) та Верховна Рада України (ВРУ) [8, 
с. 412-414]. Слід зауважити, що Верховна Рада ніколи не спрямовувала свою діяльність безпосередньо на погіршення умов діяльності НПФ (окрім, зрозуміло, зволікання із прийняттям законів щодо запровадження другого рівня пенсійної системи та професійної пенсійної системи). Навпаки, зміни, які вносилися до законодавства про недержавне пенсійне забезпечення зазвичай покращували умови інвестування пенсійних активів за рахунок розширення нормативів інвестування, а також додатково внормовували можливість та умови участі НПФ в обслуговуванні пенсійних активів другого (загальнообов'язкового) рівня. Проте послідовна деградація загального профресійного рівня виборної законодавчої влади часто призводила до прийняття колізійного законодавства, яке містило норми, що суперечили іншим законодавчим актам. Не оминула така колізійність законотворчої діяльності ВРУ й умов діяльності НПФ. Так, протягом 2015-2018 рр. внаслідок внесення змін до Податкового кодексу України (ПКУ) в частині визначення критеріїв реєстрації платника податків як неприбуткової організації не було враховано особливості спеціального законодавства про недержавне пенсійне забезпечення, яким було визначено статус НПФ як неприбуткової організації (непідприємницького товариства). Відповідно, окремі критерії нової редакції ПКУ суперечили прямим заборонам, встановленим для НПФ спеціальним законодавством. Таким чином, фінансова модель функціонування вітчизняних НПФ кілька років була спотворена як в частині податкового статусу НПФ, так і в частині податкової та фрінансової звітності цих фрінансових установ. Хоча наступні зміни до ПКУ виправили колізійні норми, визнавши їх нечинними з моменту їх прийняття, механізм відновлення статусу НПФ як неприбут- кової організації за період існування таких колізійних норм наразі відсутній.

Кабінет Міністрів України можна також цілком слушно звинувачувати у зволіканні із запровадженням другого рівня пенсійної системи (загальнообов'язкового) та професійної пенсійної системи, яка мала перевести професійні пенсії з солідарного на накопичувальний рівень. Повільна розробка, недостатній рівень підготовки відповідних законопроектів та їх неактивне просування у ВРУ [8, с. 412] гальмувало розвиток накопичувальних фрорм пенсійного забезпечення, обов'язкова складова яких, вочевидь, мала б стати основною рушійною силою у формуванні розуміння переваг і форм здійснення пенсійних накопичень у такої чисельної групи суб'єктів національної пенсійної системи, як працюючі фрізичні особи та їх роботодавці. Проте, як зазначалося вище, основна увага приділялася виконавчою владою покращенню функціонування солідарної пенсійної системи (ПФУ), до якої виявляла "електоральну чутливість” значна частина громадян-виборців, які вже вийшли на пенсію і не могли бути задіяні у накопичувальних формах пенсійного забезпечення. При цьому майже не розглядалися можливості та способи запровадження другого рівня пенсійної системи $з$ мінімізацією ризиків дестабілізації першого ії̈ рівня. Відвертим саботуванням запровадження другого рівня пенсійної системи виявилося невиконання КМУ норми закону [14], згідно з вимогами якого цей орган до 1 липня 2018 р. мав би забезпечити створення інституційних компонентів функціонування накопичувальної системи пенсійного страхування, а перерахування страхових внесків до накопичувальної системи пенсійного страхування мало бути запроваджено з 1 січня 2019 р. Враховуючи наявність моделі другого рівня, закріпленої законом [2], існувала мож- 
ливість практичної реалізації цього завдання. Отже, відповідальність за відсутність наразі другого рівня пенсійної системи повністю лежить на Кабінеті Міністрів України. Щодо впливу такого саботування розвитку пенсійної системи на діяльність НПФ, то слід нагадати, що згідно з чинним пенсійним законодавством [2] через два роки після запровадження Накопичувального фонду його учасники отримують право на переведення своїх загальнообов'язкових пенсійних накопичень до НПФ на власний розсуд. Таким чином, певна активна частина учасників Накопичувального фонду вже з січня 2021 року отримала б право на такі переведення, що значно збільшило б розмір активів НПФ, пожвавило та покращило показники їх інвестиційної діяльності та сприяло б популяризації додаткових пенсійних накопичень на третьому рівні пенсійної системи.

Висновки. Враховуючи "електоральну чутливість” питань пенсійного забезпечення, кожна каденція державної влади протягом впровадження пенсійної реформи в Україні зосереджує увагу на реформуванні солідарної складової пенсійної системи, яка охоплює значну частину громадян-пенсіонерів та політизує рішення щодо розвитку накопичувальної складової національної пенсійної системи, фактично гальмуючи запровадження загальнообов'язкових її складових (Накопичувального фонду та професійної пенсійної системи), що не матимуть швидкого впливу на електорат. Розвиток недержавного рівня пенсійної системи в політичному контексті соціально-економічного розвитку державна влада майже не розглядає.

Розвиток недержавного рівня пенсійної системи стримується як суб'єктивними так і об'єктивними фракторами. До суб'єктивних, зокрема, можна віднести необов'язковий (добровільний) характер недержавного пенсійного забезпечення, низький рівень обізнаності фрізичних осіб і підприємств-роботодавців щодо механізмів функціонування недержавного пенсійного забезпечення (зокрема, недержавних пенсійних фондів) і, відповідно, низький рівень довіри до цих фінансових установ, а також цілеспрямовані чи спонтанні дії/ бездіяльність органів державної влади, які ускладнюють умови функціонування суб'єктів недержавного пенсійного забезпечення. Об'єктивними фракторами, які стримували розвиток накопичувального недержавного пенсійного забезпечення 3 моменту його запровадження, є проблеми національної економіки, зумовлені світовими та національними економічними кризами, зокрема - високий рівень тінізації економіки та заробітних плат, випереджаюче зростання частки поточного споживання в грошових доходах населення, інфляція та девальвація національної валюти, обмежені можливості для диверсифікації внутрішніх інвестицій, тривале блокування валютної диверсифікації пенсійних активів і недостатність накопичених пенсійних активів у валютному еквіваленті для ефективного іноземного інвестування за умови валютної лібералізації тощо.

Необхідною умовою ефективного впливу державного регулювання на розвиток національної пенсійної системи в цілому та діяльність НПФ зокрема є, насамперед, дотримання органами державної влади законодавства та належне виконання покладених на ці органи завдань. Від законодавчої влади вимагається глибоке та всебічне опрацювання норм пенсійного законодавства, як такого, що зачіпає та залежить від переважної більшості соціально-економічних відносин, внормованих актами 3 різних галузей права, з метою запобігання виникнення правових колізій між нормами різних актів законодавства. Від виконавчої 
влади вимагається ефективна взаємодія із суспільством і законодавчою владою на етапі законотворчості та чітке виконання обов'язків, покладених на виконавчу владу законодавством. Від фінансових регуляторів вимагається забезпечення прозорого та всебічного економічного обґрунтування регуляторних заходів з метою уникнення волюнтаристських, відомчо упереджених або недостатньо обґрунтованих рішень. Загалом, доцільно оновити правове забезпечення процесу реформування національної пенсійної системи програмним документом, який окреслював би державну політику розвитку пенсійної системи за всіма їі складовими та механізм державного управління цим процесом.

В сучасних умовах найбільш потужним важелем розвитку недержавних пенсійних фондів може стати запровадження загальнообов'язкового накопичувального рівня пенсійної системи (Накопичувального фонду) та професійної пенсійної системи, із залученням НПФ до обслуговування обов'язкових пенсійних накопичень на економічно обґрунтованих засадах. Досвід, набутий учасниками обов'язкових складових накопичувального пенсійного забезпечення, сприятиме їх подальшому залученню до здійснення добровільних пенсійних накопичень на третьому (недержавному) рівні пенсійної системи, зокрема в НПФ. При цьому держава має надати приклад “соціальної відповідальності” для роботодавців, запровадивши на підприємствах державного сектору економіки та акціонерних товариствах, в яких держава $є$ контролюючим власником, програми додаткового недержавного пенсійного забезпечення їх працівників. Як наслідок, можна очікувати прискореної детінізації доходів населення, зокрема, заробітної плати, збільшення джерел пенсійного забезпечення населення та підвищення рівня заміщення трудо- вих доходів у старості, а також формування потужного джерела інвестиційних ресурсів для фінансування національного економічного розвитку.

\section{Список використаних джерел}

1. Holzman R., Hinz R. Old-age income support in the 21st century: an international perspective on pension systems and reform. The World Bank, Washington, D.C., USA, 2001.

2. Про загальнообов'язкове державне пенсійне страхування. Закон України від 9 липня 2003 p. № 1058-IV (зі змінамu). URL : https:// zakon.rada.gov.ua/laws/show/1058-15.

3. Про недержавне пенсійне забезпечення. Закон України від 9 липня 2003 р. № 1057-IV (зі змінамu). URL : https://zakon.rada.gov.ua/laws/ show/1057-15

4. Загреба І. І. Реформування пенсійної системи та його вплив на інвестиційну привабливість України. Науковий вісник Ужгородського національного університету. Сер. “Міжнародні економічні відносини та світове господарство”. 2018. Вип. 20, С. 159-162.

5. Лисяк Л. В. Фінансові ресурси недержавних пенсійних фондів в Україні: проблеми фрормування та можливості інвестування. Економічний вісник університету. 2017. Вип. 34(1). C. 267-274.

6. Ріппа М. Б., Шамун Н. В.. Інвестиційна діяльність недержавних пенсійних фондів в Україні. Збірник наукових праць Університету державної фоскальної служби України. 2018. № 2. С. 319-336.

7. Теслюк С. А. Розроблення концептуальних підходів до формування державної політики розвитку НПФ в Україні. Причорноморські економічні студії. 2018. Вип. 29. С. 90-95.

8. Федина В. В. Економічно-правовий аспект введення накопичувальної складової системи загальнообов'язкового державного пенсійного страхування. Трансорормація фрінансових ринків в умовах глобальної нестабільності: реалії сьогодення та погляд у майбутнє : зб. матер. 


\section{АКТУАЛЬНІ ПИТАННЯ ТЕОРІЇ І ПРАКТИКИ ФІНАНСІВ}

виїзного наук.-практ. семінару, 6-15 жовтня 2017 р. та міжн. наук.-практ. інтернет-конф., 30 жовтня 2017 р. Ірпінь : Ун-т ДФС України, 2017. С. 412-416.

9. Про додаткові заходи щодо діяльності банків. Постанова Правління Національного банку України від 11.10.2008 № 319. URL : http://zakon1.rada.gov.ua/cgi-bin/laws/main. cgi?nreg $=v 0319500-08$

10. Привернення уваги держави до проблем мільйонів клієнтів небанківських фрінансових установ потребує консолідації усіх його учасників. Київ, 2009. URL : http://www.uaib.com.ual print/news $/ 102416$. html.

11. Про внесення змін до деяких законів України щодо убезпечення пенсійних активів. Закон України від 24 травня 2012 р. № 4841-VI URL : https://zakon.rada.gov.ua/laws/show/4841-17

12. Індекси споживчих цін у 1993-2018 рр. Держстат України. URL : http://www.ukrstat. gov.ua/operativ/operativ2006/ct/cn rik/isc/isc u/ isc per u.htm

13. Ковальова В. Чи має право регулятор на вибірковий підхід? Урядовий кур'єр. 2015. № 200. URL : https://ukurier.gov.ua/uk/articles/chimaye-pravo-regulyator-na-vibirkovij-pidhid/.

14. Про внесення змін до деяких законодавчих актів України щодо підвищення пенсій. Закон України від 3 жовтня 2017 р. № 2148-VIII (зі змінами). URL : https://zakon.rada.gov.ua/laws/ show/2148-19.

\section{References}

1. Holzman, R., Hinz, R. (2001). Old-age income support in the 21st century: an international perspective on pension systems and reform. The World Bank, Washington, D.C., USA.

2. Pro zahalnooboviazkove derzhavne pensiyne strahuvannia. Zakon Ukrainy vid 09.07.2003 № 1058-IV (zi zminamy). [About mandatory state pension insurance. The Law of Ukraine]. (2003, July, 9). Available at: https://zakon.rada.gov.ual laws/show/1058-15.
3. Pro nederzhavne pensiyne zabezpechennia. Zakon Ukrainy vid 09.07.2003 № 1057-IV (zi zminamy). [About non-state pension provision. The Law of Ukraine]. (2003, July, 9). Available at: https://zakon.rada.gov.ua/laws/show/1057-15.

4. Zahreba, I. (2018). Reformuvannia pensiynoi systemy ta yoho vplyv na investytsiynu pryvablyvist Ukrainy [Reforming the pension system and its impact on the investment attractiveness of Ukraine]. Naukovyy visnyk Uzhhorodskoho natsionalnoho universytetu. Ser. Mizhnarodni ekonomichni vidnosyny ta svitove hospodarstvo - Scientific Bulletin of Uzhgorod National University. Ser. International economic relations and world economy, 20, 1 [in Ukrainian].

5. Lysyak, L.V. (2017). Finansovi resursy nederzhavnykh pensiynykh fondiv $v$ Ukraini: problemy formuvannia ta mozhlyvosti investuvannia [Financial resources of non-state pension funds in Ukraine: problems of formation and investment opportunities]. Ekonomichnyi visnyk universytetu Economic Bulletin of the University, 34(1), 267-274 [in Ukrainian].

6. Rippa, M. B., Shamun, N. V. (2018). Investytsiyna diialnist nederzhavnykh pensiynykh fondiv $v$ Ukraini [Investment activity of non-state pension funds in Ukraine]. Zbirnyk naukovykh prats Universytetu derzhavnoi fiskalnoi sluzhby UkrainyProceedings of the University of Public Fiscal Service of Ukraine, 2, 319-336 [in Ukrainian].

7. Tesliuk, S. A. (2018). Rozroblennia kontseptualnykh pidkhodiv do formuvannia derzhavnoi polityky rozvytku NPF v Ukraini [Development of conceptual approaches to formation of state policy of development of NPF in Ukraine]. Prychornomorski ekonomichni studii - Prychornomorsk Economic Studies, 29, 90-95 [in Ukrainian].

8. Fedyna V. V. (2017). Ekonomichno-pravovyi aspekt vvedennia nakopychuvalnoi skladovoi systemy zahalnooboviazkovoho derzhavnoho pensiynoho strakhuvannia [The economic and legal aspect of the introduction of the cumulative component of the system of compulsory state pension insurance]. Transformatsia finansovykh rynkiv $v$ umovakh hlobalnoi nestabilnosti: realii siohodennia ta pohliad $u$ 


\section{АКТУАЛЬНІ ПИТАННЯ ТЕОРІЇ І ПРАКТИКИ ФІНАНСІВ}

maibutnie : zb. mater. vyiznoho nauk.-prakt. seminaru, 6-15 zhovtnia ta mizhn. nauk.-prakt. internetkonf., 30 zhovtnia - Transformation of financial markets in the conditions of global instability: the realities of the present and the future: coll. mater. field science practitioner. Workshop, October 6-15 and international scientific-practical Internet-con., October 30. - Irpin: Un-t DFS Ukrainy [in Ukrainian].

9. Pro dodatkovi zakhody shchodo diialnosti bankiv. Postanova Pravlinnia Natsionalnoho banku Ukrainy vid 11.10.2008 №319 [On additional measures for the activities of banks. Resolution of the Board of the National Bank of Ukraine]. Available at: $\quad$ http://zakon1.rada.gov.ua/cgi-bin/laws/main. cgi?nreg $=v 0319500-08$

10. Pryvernennia uvahy derzhavy do problem milyoniv kliyentiv nebankivskykh finansovykh ustanov potrebuie konsolidatsii usikh yoho uchasnykiv. (2009). [Drawing the attention of the state to the problems of millions of clients of non-banking financial institutions needs consolidation of all its participants]. Available at: http://www.uaib.com.ua/ print/news/102416.html

11. Pro vnesennia zmin do deiakykh zakoniv Ukrainy shchodo ubezpechennia pensiynykh aktyviv. Zakon Ukrainy vid 24.05.2012 № 4841-VI [On amendments to some laws of Ukraine on the pro- tection of pension assets. Law of Ukraine]. (2012, May, 24). Available at: https://zakon.rada.gov.ual laws/show/4841-17.

12. Indeksy spozhyvchykh tsin u 1993-2018. [Consumer price indices in 1993-2018]. Derzhstat Ukrainy. Available at: http://www.ukrstat.gov.ua/operativ/operativ2006/ct/cn rik/isc/isc u/isc per $u$. htm.

13. Kovaliova, V. (2015). Chy maie pravo rehuliator na vybirkovyi pidhid? [Is the regulator entitled to a selective approach?]. Uriadovyi kurier - Government Courier, 200. Available at: https://ukurier. gov.ua/uk/articles/chi-maye-pravo-regulyator-navibirkovij-pidhid/.

14. Pro vnesenia zmin do deiakyh zakonodavchyh aktiv Ukrainy shodo pidvishenia pensiy. Zakon Ukrainy vid 03.10.2017 № 2148-VIII (zi zminamy). [About amendments to some legislative acts of Ukraine regarding the increase of pensions. The Law of Ukraine]. (2017, October, 3). Available at: https://zakon.rada.gov.ua/laws/show/2148-19.

Стаття надійшла до редакції 11.02.2019. 